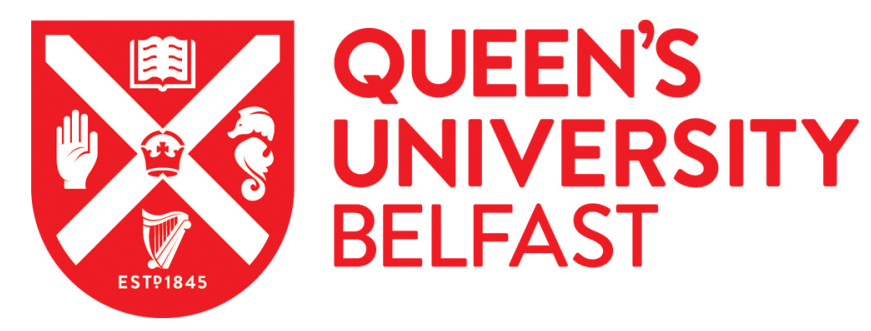

\title{
Awkward Prods:biographical studies of Progressive Protestants and political allegiance in Northern Ireland
}

Greer, J., \& Walker, G. (2018). Awkward Prods:biographical studies of Progressive Protestants and political allegiance in Northern Ireland. Irish Political Studies. https://doi.org/10.1080/07907184.2018.1454674

Published in:

Irish Political Studies

Document Version:

Peer reviewed version

Queen's University Belfast - Research Portal:

Link to publication record in Queen's University Belfast Research Portal

Publisher rights

(c) 2018 Political Studies Association of Ireland. This work is made available online in accordance with the publisher's policies. Please refer to any applicable terms of use of the publisher.

\section{General rights}

Copyright for the publications made accessible via the Queen's University Belfast Research Portal is retained by the author(s) and / or other copyright owners and it is a condition of accessing these publications that users recognise and abide by the legal requirements associated with these rights.

Take down policy

The Research Portal is Queen's institutional repository that provides access to Queen's research output. Every effort has been made to ensure that content in the Research Portal does not infringe any person's rights, or applicable UK laws. If you discover content in the Research Portal that you believe breaches copyright or violates any law, please contact openaccess@qub.ac.uk. 
Awkward Prods: biographical studies of Progressive Protestants and political allegiance in Northern Ireland

Graham Walker and James Greer[COM2]

Queen's University Belfast, Belfast, UK[AQ1] CONTACT James Greer james.greer@qub.ac.uk; Graham Walker g.s.walker@qub.ac.uk

ABSTRACT Through studies of four individuals, this article will explore the utility of biography as a method of disentangling strands of political allegiance in Northern Ireland during the era of the 'old Stormont'. The four individuals - Harry Midgley, Arthur Linden Agnew , Albert McElroy and Jack Hassard - are connected by progressive strands of political activism, Protestantism and use of UlsterScots or British identity to support their political stances. These four lives reveal much about the development of Northern Labour and Liberal politics, but as a collective biography, rather than a party or institutional history, they reveal much of the wider milieu of reformist Northern Protestants. Their diverse final political destinations highlight the tensions within this strand and the persistence of divisions in Northern Ireland.

KEYWORDS: Northern Ireland; Protestant; Labour; liberal; Ulster-Scots; biography

In a deeply divided society, such as Northern Ireland, study of those individuals on the edges of the two domineering ethnonational or religiopolitical identities, or those who occupied the gaps between the two, is often where fresh historical insights can be found. Perspectives from this precarious terrain encourage a nuanced understanding of the boundaries of allegiance in Northern Ireland. Biography, and the deep context it encourages, remains a potent method of defining these boundaries, tracing their evolution over a defined timeframe, and chronicling how the institutions of political and religious life in Northern Ireland struggled to accommodate those who placed themselves on the fault-lines. This article will explore the utility of the biographical method in a divided society through case studies of inter-connected reformist Progressive Protestants, namely: Harry Midgley, Arthur Linden Agnew, Albert McElroy and Jack Hassard. These biographies, a collective biography, reveal new dimensions to the Ulster Protestant experience from those who challenged traditional unionist orthodoxies from labour and liberal positions but remained outside of Irish nationalism. They place us in this precarious territory from the 1920s to the early 1970s: from the violent birth of the Northern Ireland state; subsequent decades of intermingled sectarian division, uneasy peace, social reform and political paralysis; fleeting Sixties progressive optimism; and through to the cataclysmic start of the modern conflict. Harry Midgley's life (1892-1957) took him from the Western Front to becoming Northern socialism's most potent challenger to Unionist Party dominance in the 1920s and 1930s, before his break from Labour and a career ending as Unionist Party Education minister (Walker, 1985). Another veteran of the First World War, Rev AL Agnew (1896-1977) was in the interwar period a prominent advocate of Christian socialism. Agnew interpreted Presbyterian and Ulster-Scots values and identity as rationales for twentieth-century cross-community labour politics. Rev Albert H. McElroy (1915-1975) was another NonSubscribing minister with British military service, this time in the Second World War, and a strong Ulster-Scots identity. Although initially politically allied with Midgleyite Labour, McElroy sought to resurrect Ulster Liberalism as the platform for reconciliation on the island (Gillespie, 1985). Jack Hassard (1926-2004) was a Protestant Labour councillor in the crucible of the civil rights crisis, Dungannon (for Hassard and Dungannon politics, see Greer, 2011, pp. 67-112). A veteran of the Second World War, and a former B-Special who joined the Ulster Defence Regiment on its formation, Hassard became a hate-figure to some local unionists and a unique voice within the Northern Ireland Civil Rights Association (NICRA) - viewing reform and working-class experience through a British lens. 
Applying the method of biography to Northern Ireland The potential shortcomings of historical biography have been concisely summarised by one of the method's most respected practitioners, Ian Kershaw . Biography, Kershaw states, 'runs the natural risk of over-personalizing complex historical developments, over-empathizing the role of the individual in shaping and determining events, ignoring or playing down the social and political context in which those actions took place' (1998, p. xxi). These pitfalls often distil into what Lucy Riall calls 'the heroic model of biography', when a biographer defines an age through the life of one powerful individual (2010, pp. 376-378). This distorting historical lens encourages elitist conceptions of how social and political change occurs and, as Riall notes, is especially open to patriarchal assumptions of exemplary lives by Great Men. Such potential distortions, however, can be navigated and biography can achieve much more than the glorification, or damnation, of a prominent individual. Biography demands temporal and subject specificity and concentration on human agency but, as Nick Salvatore states, successful biographies by historians are 'rooted in ideas and events larger than the individual subject' (2004, para. 9). Biographical studies can, in other words, achieve the clarity of focus brought by the subject but also be framed by a strong awareness of the structures - political, economic, legal, cultural and others shaping the subject's life and the context of the choices they make. As David Nasaw asserts: 'While intent on reinserting individuals into their histories as signifiers and agents, biographers do not grant them independence or autonomy in either capacity' (2009, p. 577). This intertwining of the structural with the personal opens unique opportunities to understanding how allegiances were maintained or broken in a society with stark political and cultural boundaries. Furthermore, as Lois Banner argues, the narrative template of biography foregrounds the importance of 'ancestry, kinship, family, and friendship' (2009, p. 583). These bonds and networks are central to understanding how allegiances are fashioned, and they highlight how the life of one individual can be a gateway into a wider societal study. A collective biography of individuals connected by these networks, or 'linked through a central theme' (Banner, 2009, p. 583), further expands upon this potential for biography to transcend the study of an individual life. Collective biography also encourages comparative analysis and facilitates measuring change across generations. Key, of course, is case selection. Biography can be a mode of historical recovery - focusing on individuals whose lives have been submerged by larger currents of political life. Study of individuals associated with defeated political tendencies can reveal as much as those who asserted power. To write about the arguments, campaigns and biographiers of Progressive Protestants in this period is to largely be a chronicler of political frustration and marginal voices. But, as shall be detailed below, some of the political objectives of the Progressive Protestants were to be met and their threat to Unionist Party hegemony was such that their presence is vital to understanding the dynamics of Northern Ireland politics. A final strength of biography is its popularity with the general reader and students. Schlesinger Jr. saw biography as 'rendering the past more human, more vivid, more intimate, more accessible, more connected to ourselves' (Nasaw , 2009, p. 575). At best, the intimacy of biography combined with a critical lens and a structural understanding of the subject's environment can connect readers with new perspectives on old problems.

Awkward Prods: defining the terrain This collective biography is structured around a conception of a strand of political opinion we are abridging as 'Progressive Protestants'. This strand excludes others from the political left from an Ulster Protestant background, namely those from the revolutionary left or who embraced Irish nationalism or republicanism. The allegiances and lives of the revolutionary or nationalist Protestant are highly instructive and deserving of more study, but our concern is with the 'awkwardness' of other Progressive Protestants. This strand is reformist, not revolutionary, and with regard to the constitutional question moved on the spectrum, often between small ' $u$ ' unionism and advocates of Gladstonian Home Rule. Elements of unionism 
remained keen to link this awkward strand with republicans as 'Rotten Prods', or an older category 'Lundies'. In addition to common political aspirations, our cases also share many connections of kinship. Midgley and Agnew campaigned together for Labour. McElroy and Agnew were two of the most prominent clergymen within the small but influential NonSubscribing Presbyterian Church. Midgley, Agnew and McElroy are contrasting figures in some key respects, but this trio's commonalities represent an awkward political lineage - one that cannot be restricted to one party, or church, history of one label. Hassard's connection to this lineage is less personal and shifts the geographical shiftfocus west, to Tyrone, but his role in the vital turning-point of 1968-1969 encapsulates much of the challenges of allegiance and political isolation that define the Progressive Protestant experience. Foundational to this reformist strand is its rejection of the Ulster Unionist Party (UUP). As the sole party of devolved government in Northern Ireland from 1921 to 1972, the UUP represented a coalition of Protestants encompassing comfortable majorities in all social classes, the rural and the urban, and the pews of all the main Protestant churches. On the rare occasions when the UUP's electoral dominance was threatened it was not from Northern nationalism, whose support was overwhelming limited to those from the Catholic minority, but by a fracturing of Protestant support. The main challenge in this regard was from Labour - the most accommodating political home for reformist Progressive Protestants (Edwards, 2009; Walker, 1985). Intermittently, the Northern Ireland Labour Party (NILP) were to achieve significant support, especially in Greater Belfast, peaking with 26 per cent of the overall vote in the 1962 elections to Stormont (Edwards, 2009, pp. 84-86). The apparently impenetrable position of the UUP within the Protestant community forced reformist-inclined Protestants to choose between seeking influence inside the party or unlikely success outside it. There remained clear competing tendencies and priorities within the UUP. These tensions have been described as being primarily between 'populists' and 'antipopulists' (Bew , Gibbon, \& Patterson, 2001). At other times, the clearest split was between those willing to flirt with Dominion status for Northern Ireland and those emphasising integration with the social benefits of the British welfare state (Walker, 2004, pp. 104-106). There was also a continuing liberal unionist strand within the party, best exemplified at cabinet level by Brian Maginnis.1 At a grassroots level, anti-sectarian Protestants could also seek to improve community relations and dampen civil unrest within the UUP and Orange Order. David Fitzpatrick's biography of Frederick MacNeice - poet Louis's father - provides a rigorous and insightful biographical example of this tendency (2012). Frederick MacNeice sought, and in part succeeded, to use his Protestant political capital as a Church of Ireland Orange chaplain to challenge the sectarian civil unrest of the 1930s and improve the lives of his largely working-class congregation. The question of where best to achieve reformist goals is fundamental to the Progressive Protestant experience. It was to be one of the central questions of Harry Midgley's life. Harry Midgley: negotiating Labour and the union Harry Midgley, as he often liked to recall, was a political animal from the day he, as a 14-year-old, met the Labour leader, pioneer and folk hero, Keir Hardie (see, for example, NI House of Commons Debates Vol. XVI, 6 March 1934, c.436). This led to him joining the Independent Labour Party (ILP) and imbibing the crusading zeal and moral fervour of that party's brand of socialism. These essentially British Labour influences, political and cultural, were to shape his life's work even in his later days as a Unionist minister in the government of Northern Ireland. Nevertheless, he could not avoid the entanglements of the Irish national question: indeed, for a brief period, Midgley seems to have been sympathetic to James Connolly's ideal of an Irish Socialist Republic and the severing of the British link (Walker, 1985, chapter 1). However, Midgley's opposition to the partition of Ireland, as expressed in his election address when he stood as a candidate for the first Northern Ireland Parliament, probably owed more to the pro-Home Rule position taken by the British Labour movement before the First World War. By the time he assumed the leadership of the NILP in the early 1930s, Midgley had pragmatically adjusted to the political context of the Northern State and sought eagerly to 
strengthen the relationship between the embattled NILP and the British Labour Party. Besides the memory of Hardie, Midgley took care now to honour the part played in the Labour movement's fledgling years in Ulster by William Walker who had clashed acrimoniously with Connolly in 1912 over the question of whether socialist progress could be better achieved as part of the UK or as independent of it (for accounts of this controversy, see Morgan, 1991, pp. 88-90; Patterson, 1980, pp. 79-80). The striking extent to which Northern Ireland politics divided along ethno-religious lines with Protestants voting Unionist and Catholics voting Nationalist, constricted the space for a party like the NILP . Furthermore, successive Unionist governments pledged to re-produce the social legislation passed at Westminster and remain 'step by step' with Britain in matters of welfare and social security, thus effectively neutering much of the NILP's appeal, particularly to pro-Union workers. It was a deeply frustrating political context for someone as restless, ambitious, and able as Midgley to find himself in, and only the extraordinary circumstances of the Second World War brought him the opportunity to serve in a re-constituted government in 1943 as the only non-Ulster Unionist. By this time, Midgley had quit the NILP, weary of the constant attacks from the 'Connollyite' elements whom he regarded as insular and narrowly obsessed with partition at home when Nazi-ism and fascist dictatorships were stalking Europe. Midgley could not get the NILP to commit to the constitutional position of Northern Ireland within the UK, and pledge itself wholeheartedly to the war effort, and he proceeded hastily to form a breakaway political vehicle which he called the 'Commonwealth Labour Party' (Walker, 1985, chapter 7).2 Over the course of the 1920s and 1930s, Midgley was probably the best-known and most high-profile of the political 'dissenters': those Protestants and Catholics who refused to march in time to the tribal drum beat. This alternative voice - fragmented and sometimes itself discordant - may have played a significant part in maintaining the social fabric of Northern Ireland in the face of constant 'alarms' and 'scares' relating to the national question and sectarian strife. The work of Midgley and those like him - by no means all under the Labour banner - in local government, and council chambers, in organisations such as the trade unions and the Co-operative Society, and in socially conscious church congregations, kept a multitude of causes pertaining to the lives of the poor and disadvantaged in the public eye, and brought about notable, if gradual, change. Midgley typified the British Labour concern with municipalisation and the upholding of civic virtue. He reflected that movement's faith in the power of better educational opportunities to transform society - and he eventually oversaw as Minister of Education in the 1950s the epochal reforms of the post-war era in this field. To all this endeavour, Midgley and his allies often added a strong dash of religiously flavoured rhetoric, another characteristic of the ILP from its beginnings in Northern England and

Lowland Scotland (Howell, 1983). Midgley regularly struck evangelical poses and worked hard to combat both Unionist and Nationalist condemnation of Labour and Socialism as 'unChristian'. Throughout his career, Midgley spiced his oratory with quotations from Scripture and popular hymns and spirituals. In 1938, a typical night's work involved an address to a packed Methodist Hall on the theme of 'Christian Citizenship' that encompassed such topics as unemployment, housing, schools, and maternity and child welfare (Belfast Telegraph, 15 February 1938). Midgley's Great War experience - he served in the Royal Engineers - seemed not to shake his Christian faith, 3 although it is notable that the clerics with whom he associated and whose outlook he helped to shape - the Reverends Bruce Wallace, Arthur Agnew and Albert McElroy - were all on the liberal 'dissenting' end of the Protestant spectrum. Midgley's appeals at different election times to Protestant voters often involved references to his military service for 'King and Country', as well as a determination to wrest back religious faith from his opponents to serve the cause of 'the Brotherhood of Man'. He also took to publishing his NILP and Commonwealth Labour conference speeches under such titles as 'The pilgrimage of hope' (Midgley, 1942). Midgley's work on behalf of the Catholic voters of the Dock 
constituency of Belfast, first as a Councillor then as an MP at Stormont, led him to be 'sanctified' his photograph lit up by oil lamps in numerous front windows - before being 'crucified' over his stance on the Spanish Civil War.4 Midgley's support for the Spanish Republic - the cause célèbre of the Left internationally - brought him into bitter conflict with the Catholic Church and lost him his parliamentary seat in 1938. By this time, Midgley was making the personal sacrifice of giving shelter to several Basque refugees, pro-Spanish government seamen whose ships were impounded in Belfast harbour. Spain, for Midgley, was probably the most contentious part of his long public life, eclipsing even his spells in government. It allowed him to give vent to all the crusading moral energy of his ILP heritage, it put on display his formidable propaganda skills, it called forth the conspicuous courage of a true fighter for justice and it gives him today an honourable place in Northern Ireland's 'Awkward' hall of fame. Rev Agnew - Christian socialism through conflict and world war Rev AL Agnew was a comrade of Harry Midgley through his interwar years on the frontline of Labour politics. Midgley, in turn, was a regular member of the congregation at Agnew's politicised Sunday evening services. Agnew's status is exemplified by his chairmanship of the 1938 meeting when Clement Attlee spoke alongside Midgley in Belfast (Belfast Telegraph, 13 October 1938). Agnew's contribution to Northern public life is singular. He was one of the strongest public voices advocating an explicitly theologically liberal reformed Protestantism just as a new transatlantic variation of fundamentalism was asserting itself. As a result, Agnew was a prize target of 'aggressive attacks' in conservative revivalist Presbyterian WP Nicholson's search for backsliders (Steers, 2006). Agnew was also a political provocateur and Christian socialist. As a young minister, he declared 'Why I am a Socialist' on the front of The Labour Opposition (June 1925) - the short-lived newspaper from the ILP strand of Labour edited by Scotsman Hugh Gemmell. 5 Alongside his contributions to public debate and leading role in international liberal Protestant church movements, at a local congregational level, Agnew's church was a provider of social welfare and a cultural hub. Lacking a biographer or sustained attention from a historian, Agnew's life is a fresh gateway into interwar Northern Irish politics, society and culture. Raised as a farmer's son in Moira County Down, 6 the young Agnew signed the Ulster Covenant ('Arthur L Agnew , Moira', PRONI, Ulster Covenant online). In 1916, he halted his medical studies at Queen's Belfast to join the pioneering Royal Flying Corps. After the war, Agnew trained for the ministry as a mature student at one of non-conformist Britain's most important institutions, Oxford University's Harris Manchester College.7 In 1923, he became minister of the struggling York Street NonSubscribing Presbyterian Church. The poverty of the area, its unique dockland culture and the intense local sectarian riots of the early 1920s and 1935 combined to fire Agnew with a passion to preach a socially infused gospel. York Street became The Labour Church (McClure, 1993, pp. 79-87). This was an unusual context for the Non-Subscribing denomination, mostly associated with pockets of rural eastern Ulster and more affluent Belfast congregations. Agnew joined a congregation where: Numbers were appallingly small, and it was prophesied that the congregation would disappear, but by the labours of this young man York Street had become, before very many years had passed, the largest and most successful in the whole N.S Presbyterian Church. (Article in honour of 25th anniversary of Agnew's ministry, The NonSubscribing Presbyterian, January 1949) Agnew recalled the early years at York Street: There was poverty and distress ... Men and women in this congregation stayed in bed because you could eat less that way. The church here in York Street was open every day and every night for people who had nowhere to go. (Sermon for 'Annual Service', 29 October 1934, Agnew Papers, Box 2) When snobbery was directed at the worshippers Agnew responded with a classically Christian socialist formulation: One of our critics at the beginning spoke lightly of 'the class of people that go to York Street' ... Taking them all in all with all their shortcomings and failures not forgotten - the class of people who go to York Street are the class of the Kingdom of God. (Letter to Congregation from Agnew during recuperation from illness, Agnew Papers, Box 2) Agnew saw the NILP as the political vehicle for this 
message. During the bitterly contested West Belfast election to Westminster of 1924, Agnew was a leading campaigner for Harry Midgley against the UUP's Robert Lynn. The campaign was marked by violence directed towards the Labour campaign (Irish News, 14 October 1924; Northern Whig, 14 October 1924, 5 December 1924). The heated local context, the entry of a Sinn Féin candidate splitting the anti-unionist vote, and the dominance of the imminent Boundary Commission issue, all helped Lynn increase his majority, but Labour maintained a striking level of support in Protestant areas. 8 Key to Midgley's campaign was repelling UUP attacks on him as a Bolshevik and Sinn Féinera 'Rotten Prod'. Midgley responded by referencing his Protestant upbringing and war record and by employing the support of Labour supporting Protestant clerics. At an Ulster Hall rally for Midgley Agnew launched an attack on aspects of the Unionist campaign, alluding to the militant loyalist interventions of Presbyterian minister, poet and Lynn supporter WF Marshall (Irish News, 28 October 1928). Then he proceeded to sarcastically highlight the war records of Midgley and himself in contrast to Lynn's lack of service, before concluding his speech with a sweeping denouncement of Unionist voters as ' 10,000 yahoos' and the BSpecials as 'B stands for bricks, bottles, booze and the Boundary' (Northern Whig, 28 October 1928). Agnew's speech and its 'loud-mouthed and senseless vulgarianism', met unsurprisingly with a furious response from the Belfast unionist press (Belfast Telegraph, 28 October 1924).

Strikingly the 1924 campaign became, in part, a parallel battle for Presbyterian political legitimacy. As editor of the Northern Whig Lynn was the embodiment of the new generation of conservative Presbyterians now, somewhat uneasily, within the Unionist establishment. In contrast, Agnew employed the language of Presbyterian moral seriousness and egalitarianism to support the cause of Labour. The radicalism of his brand of Presbyterianism and Ulster-Scots identity were common themes for Agnew on political platforms and in the pulpit. For Agnew, 'Burns was a prophet' and the founders of the Non-Subscribing church acted in 'the interests of liberty and the spirit of the Protestant Reformation and true Presbyterianism' (Agnew Papers, Box 1. Sermon honouring an anniversary of the formation of Non-Subscribing Remonstrant Synod of Ulster, date unrecorded). Agnew spoke of this tradition as having empathy for the 1798 Rebellion and a unionist framework. Henry Montgomery, the most notable individual in the history of the church, was seen by Agnew as: 'Sympathetic with the Presbyterian Rebellion of 1798 and loyalty to the British connection ... A champion of the spirit of liberalism that is the proper genius of Presbyterianism, and belief in order and good government and liberty.' When describing the ethos of the church to Sunday school children Agnew surmised the denomination as 'the most Protestant of the churches' due to its concentration on the liberty of conscience (Agnew \& McCleery, 1942, p. 3). Rarely in Northern Ireland has Protestantism been as clearly, or bluntly, co-opted for liberalism. Patricia Craig suggests Brian Moore's character Rev McMurty in the definitive Belfast Second World War novel The Emperor of Ice Cream 'probably owes something, though not everything' to Agnew (1995). For the naïve young Catholic protagonist in the novel, the minister, a bohemian socialist, is a hopeful exotic template: 'He had never met a Protestant minister before, but the Reverend McMurty fitted his preconception perfectly' (Moore, 1987, p. 96). Craig describes Agnew as 'the unofficial pastor to the intellectual set and outspoken opponent of sectarianism, vulgar prurience and narrow-mindedness of any sort' (1995, p. 139). This places Agnew at the heart of the cultural resistance to staid conservatism that Parr has vividly located in a radical strand of twentieth-century Protestant writing (2017). Agnew , for example, was a regular patron of Campbell's Café and Davy McClean's Progressive Book Shop - key institutions for the 'Progressive Bookmen' of 1930s Belfast (Longley, 1986). Agnew and with his wife Isobel Caldwell, a prominent medical doctor in the city, were friends of John and Roberta Hewitt. The poet admired Agnew's preaching and attended a men's fellowship group at York Street for a time (McCormack, 2015, pp. 28, 99, 102). Another worshipper at York 
Street was the playwright Thomas Carnduff (Parr, 2017, p. 64), and the church was the venue for some of the earliest performances of his work. As a cultural hub, the church attracted an eclectic audience - the leader of Belfast nationalism Joe Devlin was a patron, alongside regular worshippers, Labourites, 'the intellectual set' and York Street locals tempted by warm surroundings. Echoing Agnew, Moore's character Rev McMurty is recalled as: 'He used to be known as the Red Reverend. Spoke all over the place, raising money for the Loyalists in the Spanish War'[AQ4]"' (1987, p. 96). Alongside concern for Spain - Agnew and his wife hosted refugees and assisted in fund-raising - Rev Agnew also gave lectures across Northern Ireland regarding his experiences travelling ' 4000 Miles Through Russia' (Lecture at Victoria Hall, Larne, 16 April 1937, Agnew Papers, Box 2). Notes from these lectures suggest Agnew avoided being 'a useful idiot' for the Soviets - raising concerns about religious freedom and civil liberties - but was susceptible to claims made for Soviet planning. Throughout the 1930s, Agnew resisted calls from within the NILP to stand as a candidate (Belfast News Letter, 27 January 1938). An apparent waning of party political commitment then followed the key turning-point in Agnew's ministry - the destruction of the York Street church by the Luftwaffe in April 1941 (McClure, 1993, pp. 81-87). The bombing of the area killed 35, including at least three members of Agnew's church, and the fire and collapse of York Street Mill has been called 'Perhaps the worst single incident' of the horrors of the blitz (McGimpsey, 1984, p. ix). Agnew's York Street church was never rebuilt. Instead, the 'Labour congregation' joined with the All Souls NonSubscribing church in south Belfast under Agnew's continued ministry until his death in 1977. Agnew remained an influential liberal public figure, as a Justice of the Peace, a theologian who resisted what he saw as the drift towards non-Christian humanism within the liberal churches and as Chairman of Northern Ireland's RAF Association. These contributions and his earlier forays onto Northern Ireland's fault-lines require further study. Albert McElroy's Liberal's Ulster Just as Agnew sought to link nineteenth-century Ulster Liberalism with twentieth-century Christian socialism, a younger colleague embarked on a reverse journey. McElroy was born on 14 February 1915 in Glasgow to Ulster-born mainstream Presbyterian parents, as Gordon Gillespie details in his detailed memorial pamphlet $(1985$, p. 9). The family moved to south Co. Derry when Albert was 15 . After graduating from Trinity McElroy became secretary of the NILP and a Labour councillor in Magherafelt (Obituary notice, Belfast News Letter, 14 March 1975). In a further echo of Agnew's life, McElroy commenced a medicine degree before war intervened. At the war's end in 1945, Sergeant McElroy stood as a candidate for Stormont in the Ards constituency, but McElroy was now under the banner of Harry Midgley's new Commonwealth Labour Party (CLP) (PRONI, Albert McElroy Papers. Election poster, D3342/A/1). In the pages of the party's Justice journal McElroy explained the CLP's support for 'the creation in Northern Ireland of a Labour Government pledged to the maintenance of Northern Ireland as an integral part of the United Kingdom and the British Commonwealth of nations' ('Our Political Aims and Objects', Justice, February 1946, n.p.). He supported this stance through reference to the progressive potential and material benefits of the Union in comparison to 'narrow nationalism and parochialism of the Eire state', the war effort and the defeat of fascism, and by acknowledging 'emotional or ideological' attachment to Britishness. With the dissolution of the CLP in 1947 McElroy returned to the NILP, but despite further attempts to gain election under the Labour banner, disillusion with 'doctrinal socialism' eventually led him towards new political pastures (Belfast News Letter, 14 March 1975). Along with Sheelagh Murnaghan, McElroy led the reformation of the Ulster Liberal Party (ULP) in 1956 (Gillespie, 1985, pp. 12-16; Rynder, 2006). For McElroy, the formation of new political and religious allegiances had coincided. Informing his new Liberalism was training in theology, like Agnew, at Harris Manchester College. He was ordained as minister at Newtownards Non-Subscribing Presbyterian Church in 1954. For McElroy, there was an intellectual coherence and strong historical foundation to his new twin religious and political commitments. His sermons, newspaper columns and political speeches overflow with references to 
Presbyterian radicalism. Within one article, McElroy could place this tradition within a British context, arguing liberalism's 'roots lie deep in Presbyterianism and English Protestant Dissent', or he could articulate the tradition's sympathies with Irish republicanism, stating: The one hope for Ireland is that our people will once again recapture the spirit of their forebears. Our people led Ireland in 1798 ... Let us not forget ... James Hope, Steel-Dickson, Henry Joy-McCracken, Porter, Orr and the rest derived their strength and integrity of character from their Presbyterian religion. (Gillespie, 1985, p. 16; Newtownards Spectator, July 1955) McElroy's new allegiances took him from CLP unionism to embracing variations of the old Liberal pro-Home Rule position and support for 'ultimate' unification of Ireland. The irony for the ULP was that their only elected Stormont MP Sheelagh Murnaghan - MP for Queen's University between 1961 and 1969 - was a Catholic from a family with strong nationalist credentials who

personally leaned towards maintaining the constitutional status-quo (Rynder, 2006, p. 448). Seeking election in 1965 as Stormont member for Enniskillen, McElroy was heckled by unionists for his belief 'in the ultimate unity of Ireland as something towards which we ought to work' (Impartial Reporter, 25 November 1965). McElroy responded by declaring 'I fought for six years for my country's freedom and I am going to speak', before muddying the constitutional waters further by suggesting: 'I look forward to the day the Union Jack and the Tricolour will fly side by side at Stormont.' But, again, McElroy's main rhetorical appeal to sceptical Protestant audiences was the memory of 'the brave men and women of 1798' and the Presbyterian heritage of the American Revolution (Impartial Reporter, 25 November 1965; Fermanagh Herald, 27 November 1965). Earlier, in 1961, the Royal U Ister Constabulary (RUC)[AQ5] collected a report on how a mainly nationalist audience in Ballycastle Co. Antrim responded to McElroy's re-imagining of Liberalism (RUC 'Special Report on Albert $\mathrm{H}$ McElroy, Minister of Newtownards Non-Subscribing Presbyterian Church', PRONI, HA/32/1/1/1368. Issued 24 July 1961). The officer recorded McElory's recent anti-partition shift, noting with surprise that 'during the war years he had been very friendly with the late Harry Midgley'. The Irish News report attached to the police file highlights McElroy's honouring of the men of ' 98 and Presbyterian republicanism (Irish News, 3 July 1961), but the RUC report notes that McElroy's insistence that 'Ireland shall be free but in Commonwealth and close to Great Britain', his condemnation of recent IRA murders of police officers, and his support for the Orange Order's right to march were not received well by the audience or chair. The officer concluded: 'I do not consider that the Nationalist people of the Glens of Antrim will be very much influenced by what the Rev Mcllroy [sic] said to them.' In Ballycastle, as in Enniskillen, Liberal pluralism, with Presbyterian history as a bridge between the two communities, was insufficient to create new allegiances. As the Sixties progressed, the election of Murnaghan and the surge in support for the NILP seemed to point towards a progressive moment for the North. Both the NILP and Murnaghan used this platform to pursue civil rights reform through lobbying and parliamentary pressure (for the NILP's civil rights agenda see Edwards, 2009, pp. 127-131, and for Murnaghan's attempt to pass Human Rights law at Stormont see McElroy, 1967). But many of the strands of the 'awkward' Progressive lineage were uneasy about taking demands for civil rights to the streets. Those such as Christian socialist David Bleakley and the Liberal McElroy were outright opposed. In June 1969, McElroy, preaching on his retirement as Moderator, interpreted that 'elements of the Civil Rights movement have succeeded in promoting head-on old time Protestant-Catholic confrontations ... The situation is fraught with great danger' (Gillespie, 1985, pp. 26-27). Jack Hassard and the fault-line of the civil rights crisis While McElroy distanced himself from the Civil Rights movement (CRM), some other Progressive Protestants such as Jack Hassard placed themselves on the frontline. As his Irish Times obituary notes: 'What made Hassard unique was that he was a working-class Protestant in a bitterly divided town who took a public stand for civil rights' (Irish Times, 24 July 2004). Born in Fermanagh, as a teenager, Hassard 
volunteered for the Royal Inniskilling Fusiliers when the Second World War was declared and was 'twice mentioned in dispatches' as they fought through North Africa and Italy ('Ulster War Hero Slams BritishBush Plan', Daily Mirror, 14 February 2003). Out of the army, Hassard settled in Dungannon as a Royal Mail clerk and volunteered for the exclusively Protestant B-Specials (short biography of 'Comrade Jack Hassard', in Tyrone Courier, 23 December 1970). Simultaneously, through trade union activism Hassard gravitated towards Labour politics, becoming the driving-force of the NILP in the area, and to this day its only elected Labour councillor. Dungannon Urban District Council soon became the centre of a storm engulfing Northern Ireland. Under Unionist control, the council epitomised much of the anti-Catholic discrimination and opposition to reform that marked local government west of the Bann (Greer, 2011, pp. 77-83). Complexity should be added to conceptions of uniform discrimination in Unionist maladministration, or accounts of Protestant 'privilege' in the area, but the politically motivated refusal of the Unionist council to implement fair housing allocation or other reforms came to symbolise the wider failure of the state to provide equal citizenship for the nationalist minority. Frustrated at the slow pace of reform Hassard commented: 'I feel that Captain O'Neill's wind of change will need to reach hurricane force before it is even considered a mild breeze in Dungannon' [AQ6](Dungannon Observer, 16 March 1968). After working with Nationalist MP Austin Currie, republicans and others in organising petitions and surveys, Hassard then participated in the first NICRA march - held in August 1968, from Coalisland to Dungannon. At the conclusion of the march, Hassard spoke from the platform, demanding British rights for British citizens, along with Belfast NILP colleague Erskine Holmes. Other contributions were not so temperate. Currie referred to 'Orange bigots' and Gerry Fitt pointed to the RUC as 'black bastards', and after official platform proceedings, republican Kevin Agnew led the crowd in a rendition of 'The Soldier's Song' (Hanley \& Millar, 2009; Prince, 2007, pp. 121-122[AQ7]). The majority of the local Protestant-unionist community felt uneasy or actively hostile towards the CRM. Prior to the campaign taking to the streets there had some notable support from some local Protestants for a more moderate reform agendatactics. The future UUP MP for Fermanagh and South Tyrone Ken Maginnis was part of a local delegation lobbying for reform of the local council in 1964 (McCluskey, 1989, p. 184). But the context of 1968 was one of almost complete polarisation and Hassard's unique biography placed him on the fault-line. To the Paisleyite Protestant Telegraph, he was 'the contemptible Jack Hassard' (7 September 1968). Against shouts of 'Lundy', Hassard utilised his military and B-Specials service. During one heated exchange with a Unionist councillor, Hassard asserted: 'I defended the constitution of this country against the IRA, lying on the Border when you were dodging about Dungannon' (Dungannon Observer, 16 March 1968). But the intimidation only worsened. During unrest following a CRM meeting Hassard and his wife were attacked (Tyrone Courier, 11 December 1968). Later Hassard joined the Ulster Defence Regiment only to encounter some of those who had attacked him among the ranks of new recruits (Tyrone Courier, 20 May 1970). With the escalation of conflict Hassard also became increasingly isolated within the CRM, as the movement's agenda became more clearly influenced by the Official republicanism and other radical forces. Hassard's 'awkwardness' is further highlighted by his role in the 1969 'Crossroads' election, when he supported the O'Neillite Independent Unionist candidate, and retired Presbyterian minister, Rev Gerry Eakins in his close battle with the anti-O'Neillite UUP's John Taylor. Hassard stated that: 'My destiny is with Great Britain and if we ever are unfortunate enough to get the Craig-Taylor UDI Home Rule, which they have advocated then we cannot expect to stand alone for long as an independent state' (Tyrone Courier, 5 February 1969). Hassard left the NILP after its refusal to oppose internment without trial in 1971 (Edwards, 2009, p. 182) but remained prominent. He stood unsuccessfully in support of the Sunningdale agreement in 1973s Assembly elections, resigning from the Police Authority in opposition to police interrogation techniques, and returning as an Independent councillor from 1977 to 1981 . However, it was the fury 
of 1968-1969 in Dungannon that was to define Hassard's political life. It is often forgotten that 24 hours prior to the Battle of the Bogside violence erupted in Dungannon, when unionist and nationalist crowds confronted each other after a council meeting (Scarman Report, 1972, pp. 8991). The adjoining streets from where the crowds had

gathered, Scotch Street and Irish Street, resonated with the divided political allegiances that had brought the two groups onto the streets, and which symbolised the failure to find a progressive Ulster. Conclusions Together this collective biography reveals how strands of Protestant opinion attempted to utilise their religion, cultural identities as Ulster-Scots or Dissenters, ties to British institutions, and military service in order to challenge established political allegiances. Their lives reveal much about the relationship between conflict, religious belief and identity, social class, and the (largely) frustrated attempts to construct a third way in twentieth-century Northern Ireland. This collective biography does not claim to examine all the aspects of each individual's complex political journey(s), but it does point us towards certain key common themes. Perhaps most striking is the common role of conflict - both international and local - in shaping the allegiances and political choices they made. Agnew and McElroy highlight the continuing use of UlsterScots, or Presbyterian, history as a bridge between the two communities and a resource for radicals to gain political legitimacy within unionist communities. This article has highlighted the utility of biography in revealing the plurality of voices, and strands of religious and political thought within Northern Protestantism - including threads such as Christian socialism neglected by the literature. In the religious, cultural, class, ancestral and political brew that informs allegiance in Northern Ireland biography of those on the fault-lines requires further exploration.

Funding

[AQ2]Research for this article was funded by the Northern Ireland Department of Communities[AQ3].

Notes

1. From 1945 until 1964, Maginnis moved from the Ministries of Labour, Commerce, Home Affairs and Finance, and the post of Attorney General (Walker 2004, p. 292). 2. The new party was decidedly Christian socialist in character. 3. His book of poetry Thoughts from Flanders (Belfast, 1924) contains several religious-themed poems. See also his reflections on his religious upbringing in NI House of Commons Debates Vol. XVII, 22 November 1934, c. 138. 4. Information from Murtagh Morgan, a colleague of Midgley in the NILP in the 1920s (see Walker 1985, chapter 6). 5. See Joe Keenan's Introduction to The Labour Opposition of Northern Ireland: Complete Reprint of Northern Ireland's First Labour Newspaper, 1925-26 (Belfast: Athol Books, 1992). 6. Biographical overv iews of Agnew: The Non-Subscribing Presbyterian, January 1949; March 1953; Courtney (2014, pp. 100324102325). Obituaries: Belfast Telegraph, 28 January 1977; Belfast News Letter, 28 January 1977. 7. Agnew's substantial private papers - including correspondence, sermons, lectures and political pamphlets - are kept at Harris Manchester College, Oxford. 8. In 1923, in a straight fight Lynn held a majority of 2720 over Midgley. In a three-way contest in 1924, Lynn's majority over Midgley rose to 7313 in 1924: www.electionsireland.org. Disclosure statement No potential conflict of interest was reported by the authors[AQ8].

\section{References}

Agnew , A. L., \& McCleery , J. (1942). The story of the Non-Subscribing Presbyterian Church of Ireland: Told for its Sunday Schools. Lurgan: LM Press.[AQ9] 
Banner , L. W. (2009). Biography as history. The American Historical Review, 114(3), 579-586.

Bew , P., Gibbon , P., \& Patterson , H. (2001). Northern Ireland 1921-2001: Political forces and social classes. London: Seriff.

Courtney , R. (2014). Dissenting voices: Rediscovering the Irish progressive Presbyterian tradition. Belfast: Ulster Historical Foundation.

Craig, P. (1995). The liberal imagination in Northern Ireland prose. In E. Patten (Ed.), Returning to ourselves - second volume of papers from the John Hewitt international summer school (pp. 130144). Belfast: Lagan Press.

Edwards , A. (2009). A history of the Northern Ireland labour party: Democratic socialism and sectarianism. Manchester: Manchester University Press.

Fitzpatrick, D. (2012). Solitary and wild: Frederick MacNeice and the Salvation of Ireland. Dublin: Lilliput Press.

Gillespie , G. (1985). Albert H. McElroy: The Radical Minister, 1915-1975. Dunmurry: Albert McElroy Memorial Fund.

Greer , J. (2011). Losing the province: Ulster unionism, a localised study 1968-74 (PhD thesis). Queen's University Belfast, Belfast.

Hanley, B., \& Millar , S. (2009). The lost revolution: The story of the official IRA and the workers' party. Dublin: Penguin Ireland.

Howell , D. (1983). British workers and the ILP. Manchester: Manchester University Press.

Kershaw , I. (1998). Hitler: Hubris, 1889-1936. London: Allen Lane.

Longley, E. (1986). Progressive Bookmen: Politics and Northern Protestant writers in the 1930s. The Irish Review, 1, 50-57.

McClure , E. (1993). Bodies in our backyard. Lurgan: Ulster Society.

McCluskey , C. (1989). Up off their knees. Galway: Conn McCluskey Associates.[AQ10]

McCormack , W. J. (2015). Northman: John Hewitt (1907-87): An Irish writer, his world, and his times. Oxford: Oxford University Press.

McElroy , A. (1967). Discrimination, National Civil Liberties League: Coinsias, conscience, pp. 11-14. Dublin.[AQ11]

McGimpsey, C. (1984). Bombs on Belfast, the Belfast Blitz 1941. Belfast: Pretani Press.

Midgley , H. (1942). The Pilgrimage of Hope. Belfast: Northern Ireland Labour Party.[AQ12]

Moore , B. (1965/1987). The emperor of ice cream (1st ed.). London: Paladin.

Morgan , A. (1991). Labour and partition: The Belfast working class 1905-23. London: Pluto.

Nasaw , D. (2009). Introduction. The American Historical Review, 114(3), 573-578.

Parr , C. (2017). Inventing the myth: Political passions and the Ulster protestant imagination. Oxford: Oxford University Press. 
Patterson, H. (1980). Class conflict and sectarianism: The protestant working class and the labour movement, 1868-1920. Belfast: Blackstaff Press.

Prince , S. (2007). Northern Ireland's '68: Civil rights, global revolt and the origins of the troubles. Dublin: Irish Academic Press.

PRONI, Ulster Covenant online. Retrieved from

https://apps.proni.gov.uk/ulstercovenant/image.aspx?image=M0028690006

Riall , L. (2010). The shallow end of history? The substance and future of political biography. Journal of Interdisciplinary History, 40(3), 375-397.

Rynder , C. (2006). Sheelagh Murnaghan and the struggle for human rights in Northern Ireland. Irish Studies Review, 14(4), 447-463.

Salvatore , N. (2004). Biography and social history: An intimate relationship. Labour History, 87, 187192.

Scarman Report. (1972, November). Violence and civil disturbances in Northern Ireland in 1969 report of tribunal of inquiry (Cmd. 566). Belfast: HMSO.

Steers, R. D. (2006, July). 150 years of York Street church. Belfast: The Non-Subscribing Presbyterian.

Walker , G. (1985). The politics of frustration: Harry Midgley and the failure of labour in Northern Ireland. Manchester: Manchester University Press.

Walker , G. (2004). A history of the Ulster Unionist Party: Protest, pragmatism and pessimism. Manchester: Manchester 